\title{
3 - Experimental model in rat for sentinel node biopsy ${ }^{1}$
}

\author{
Renato Santos de Oliveira Filho ${ }^{2}$ \\ Geruza Rezende Paiva ${ }^{3}$ \\ Jairo Wagner ${ }^{4}$ \\ Solange Amorim Nogueira ${ }^{5}$
}

\begin{abstract}
Oliveira RS, Paiva GR, Ferreira LM, Wagner J, Nogueira AS. Experimental model in the rat for sentinel node biopsy. Comparision between dextran and phytate. Acta Cir Bras [serial online] 2003 Vol 18 Special Edition. Available on URL: http://www.scielo.br/acb.
\end{abstract}

\begin{abstract}
Although sentinel node procedure has been used world wide, there are many aspects to be defined and better standardized. This study address if the experimental model in rats is appropriate for sentinel node biopsy. In this model, the lymph nodes are showed by lymphoscintigraphy, they are dyed by patent blue and identified by intraoperative gamma probe detection. It isn't necessary to use magnification for the procedure. The model demonstrated that sentinel node biopsy in rats is feasible. So, besides allowing researches in this field, the model is useful for training and diffusing this technique.
\end{abstract}

KEY WORDS - Lymph node biopsy. Experimental model. Rats.

\section{Introduction}

The fear of micro metastasis has justified radical lymph node dissections on the purpose to promote cure. Nevertheless, the real benefit of such a procedure is yet to be known and its universal adoption may be of damage especially for those without lymphatic invasion. ${ }^{1}$

The sentinel lymph node biopsy has emerged by the end of the $20^{\text {th }}$ Century as a less aggressive procedure to detect micro metastasis in tumor drainage node chain. Following the procedure, only patients with positive sentinel lymph node (those in which metastasis are detected) undergo radical dissections and patients without metastasis are preserved, avoiding complications as infection, sensibility disturbances and edema., ${ }^{1,2}$

Although the signification of sentinel lymph node (the first of a chain which drains the primary tumor) has been previously proposed, the procedure has deserved respect and became the spot of interest after the description of the lymphatic mapping by the end of the eighties by Morton et al. ${ }^{3}$ In the beginning it was used in melanoma and now has been applied in other solid tumors, especially those, which spread through lymphatic vessels, like breast cancer.

1. This research was developed at Plastic Surgery Division of Surgery Department - Federal University of São Paulo - Paulista School of Medicine - UNIFESP-EPM. Brazil.

2. Professor of Post-graduation Program. Plastic Surgery Division of Surgery Department - Federal University of São Paulo - Paulista School of Medicine - UNIFESP-EPM. Brazil.

3. Post-graduation student Plastic Surgery Division of Surgery Department - Federal University of São Paulo Paulista School of Medicine - UNIFESP-EPM. Brazil.

4. Physician Coordenator, Nuclear Medicine Service, Hospital Israelita Albert Einstein. Brazil

5. Biomedicine Coordenator, Nuclear Medicine Service, Hospital Israelita Albert Einstein. Brazil 
The so called sentinel lymph node procedure involves three phases as follows: (1) pre-operative lymphoscintigraphy, (2) biopsy of the sentinel node - by means of intra-operative gamma detection and blue dye lymph mapping and (3) examination of histological sections of the node.

The pre-operative lymphoscintigraphy is fundamental and leads to the identification of the lymph node chains that may present metastatic disease and where the sentinel node must be searched. For the exam, a radiotracer is injected intradermal around the tumour or just near the scar of the tumor resection. ${ }^{4}$ The most used tracer is the meta stable shape of technetium $\left(\mathrm{Tc}^{99}\right)$ that is routinely used in most nuclear medicine procedures since it presents proper amount of energy to be detected in a gamma camera. ${ }^{6}$ Other radiopharmaceuticals can be used like colloid sulphur, human albumin, phytate and dextran. In Brasil dextran 500 and phytate are the available radiophamaceuticals pattem. ${ }^{7,8}$ It is established that there is a narrow relation between the size of the radiopharmaceutical and its properties of diffusion and of delay in the lymph node, the bigger the particle, lesser the diffusion and higher the retention in the lymph node. ${ }^{9}$

The lymphatic mapping with the blue dye simulates the anatomy of the lymphatic way the tumor cell could have followed from the primary lesion and dyes the sentinel lymph node leading to its identification. ${ }^{5}$

The intra-operative gamma detection by means of a portable gamma radiation probe permits easer localization of the sentinel lymph node in a less aggressive dissection and complements the blue dye mapping in its search. ${ }^{4,10}$ Most of times it is possible to make the search, with the probe intra-operatively, of the same radiopharmaceutical injected for the pre-operative lymphoscintigraphic exam.

Sentinel node biopsy is included as part of melamoma staging (AJCC 2002). ${ }^{1}$ It will probably have a great development during the $21^{\text {st }}$ Century and will determine a special approach for solid tumors. Molecular biology (RT-PCR) will contribute for the detection of micro metastasis and the robotics will allow sentinel node biopsy from difficult anatomic sites. ${ }^{11}$

Although the sentinel node biopsy has been adopted world widely, aspects as which would be the best radiopharmaceutical are yet to be defined and standardized. Experimental models could contribute for advances in this technique.

\section{Proposition}

To report a model for experimental sentinel node biopsy in rat.

\section{Method description}

\section{Presentation of the model}

The lymphatic system of the rat has already been studied and described. ${ }^{12}$ In this experimental model young male rats (rattus norvegicus: albinos variety, rodentia, mammalia) with weight varying from 300 to $350 \mathrm{gr}$, from the wistar epm-1 line of the federal university of são paulo - escola paulista de medicina were used and kept in twin cages under the same conditions of temperature $\left(20-21{ }^{\circ} \mathrm{c}\right)$, humidity (ambiental humidity) and noise (acoustic isolation), receiving commencial ration (purina labina) and water "ad libitum".

\section{Procedure}

The animals were anesthetized with chloridrate of tilethamine and chloridrate of zolazepan either each in the concentration of $25 \mathrm{mg} / \mathrm{kg}$ of weight by means of injections with an insulin type syringe and needle in the left distal aspect of the peritoneal cavity. This concentration granted about 120 to 180 minutes of anesthesia and in those cases it was necessary, additional doses of $10 \mathrm{mg}$ were injected. 


\section{Lymphoscintigraphy}

For lymphoscintigraphy, $0.1 \mathrm{ml}$ of the radiopharmaceutical carrying $15 \mathrm{uci}$ of $\mathrm{tc}^{99}$ was injected intradermal into left footpad of the rats. The exam was caried in a mobile gamma camera at the Hospital Israelita Albert Einstein (apex spx 4m-ge) (Figures 1, 2A and 2B).

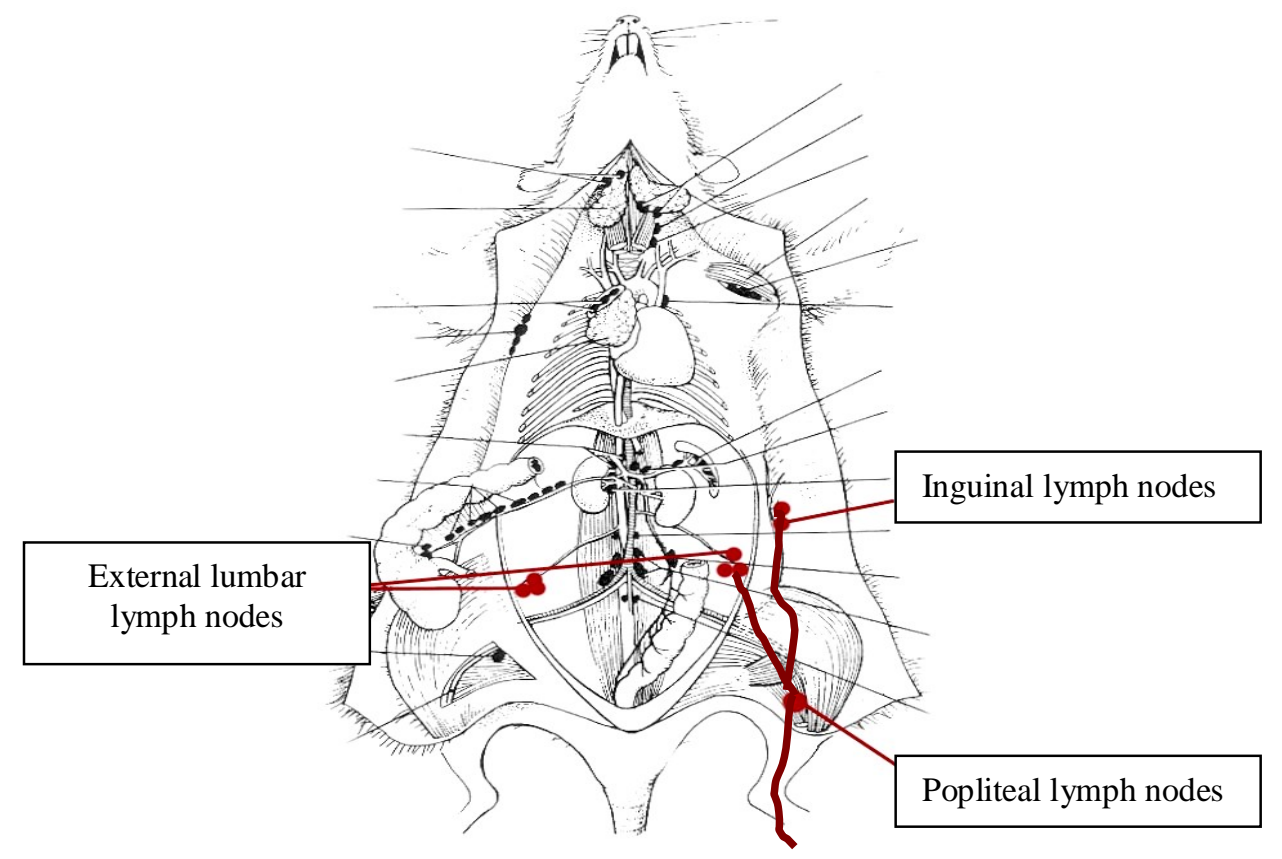

FIGURE 1 - Anatomy of lymph nodes in rats (modified from Tilney, 1971). Lymph nodes of posterior foot were stressed.

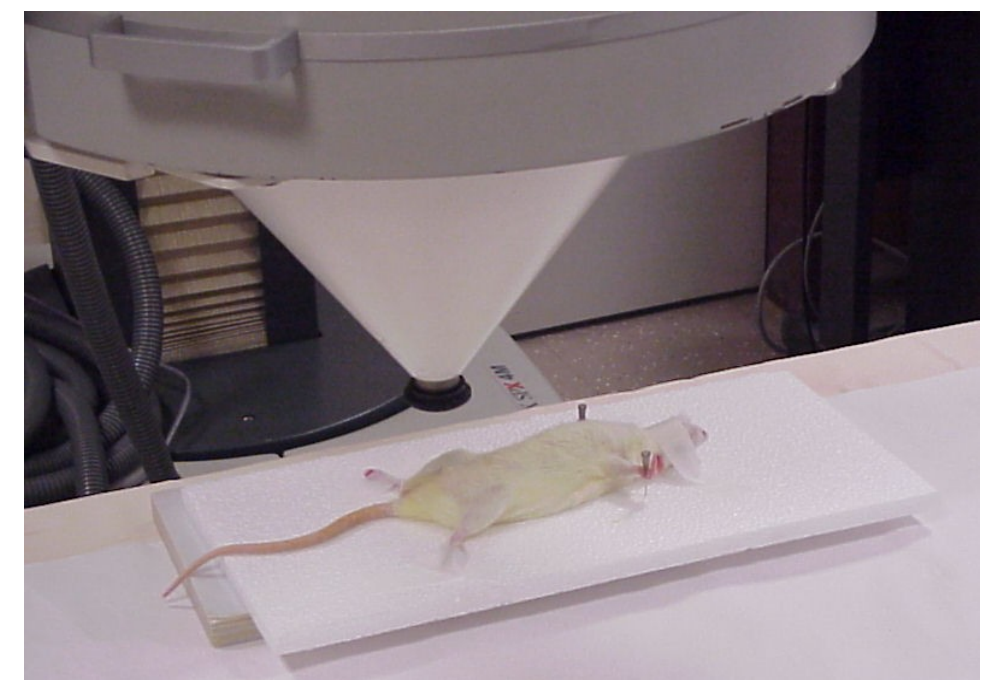

FIGURE 2A - Lymphoscintigraphy (APEXSPX 4M - GE). 


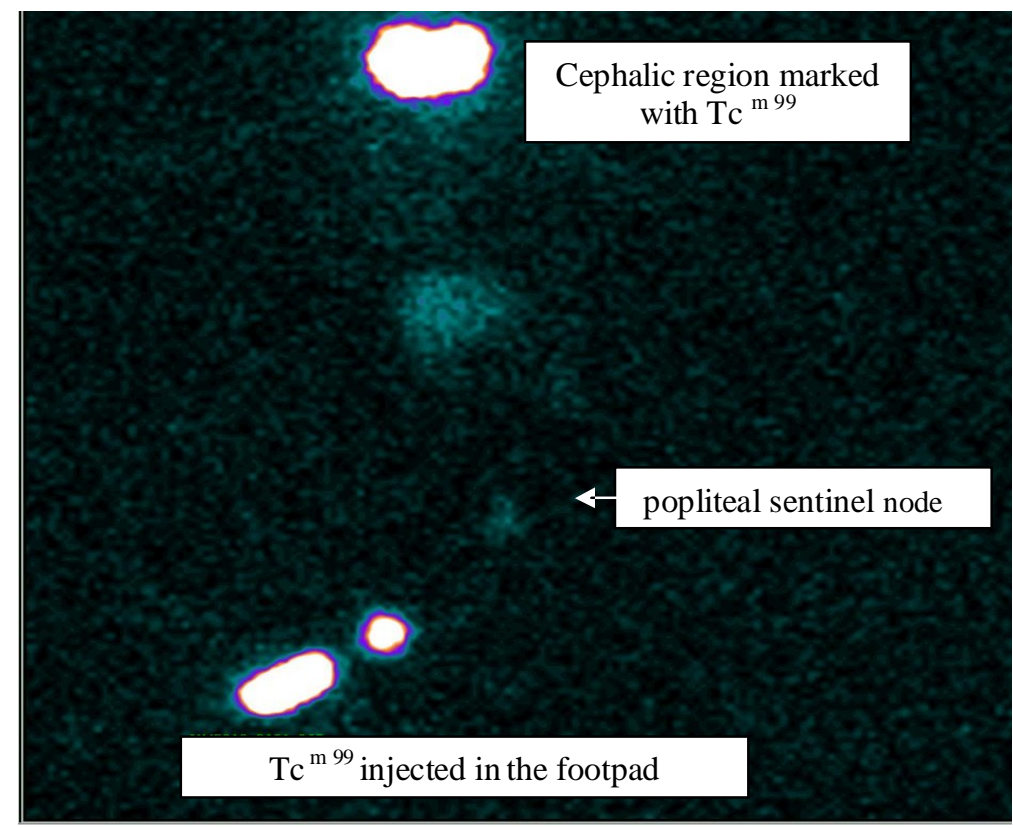

FIGURE 2B - Lymphoscintigraphy showing popliteal sentinel node.

\section{Sentinel lymph node biopsy}

One hour after the lymphoscintigraphy, a tonsure of the popliteal region of the right posterior limb was performed followed by the intradermal injection of $0.1 \mathrm{ml}$ of the blue dye (patent blue $\mathrm{V}$, Guerbet) into right posterior footpad (Figure 3). After five minutes from the injection, an incision was made in the popliteal skin of the same limb to expose its deep aspect. The popliteal, the inguinal and the lombar lymph nodes were found, all dyed in blue (Figure 4). Then, the radioactivity in these lymph nodes was checked "in loco" as well as "ex-vivo" after the biopsy. The radioactivity of left foot pad (background) was measured too.

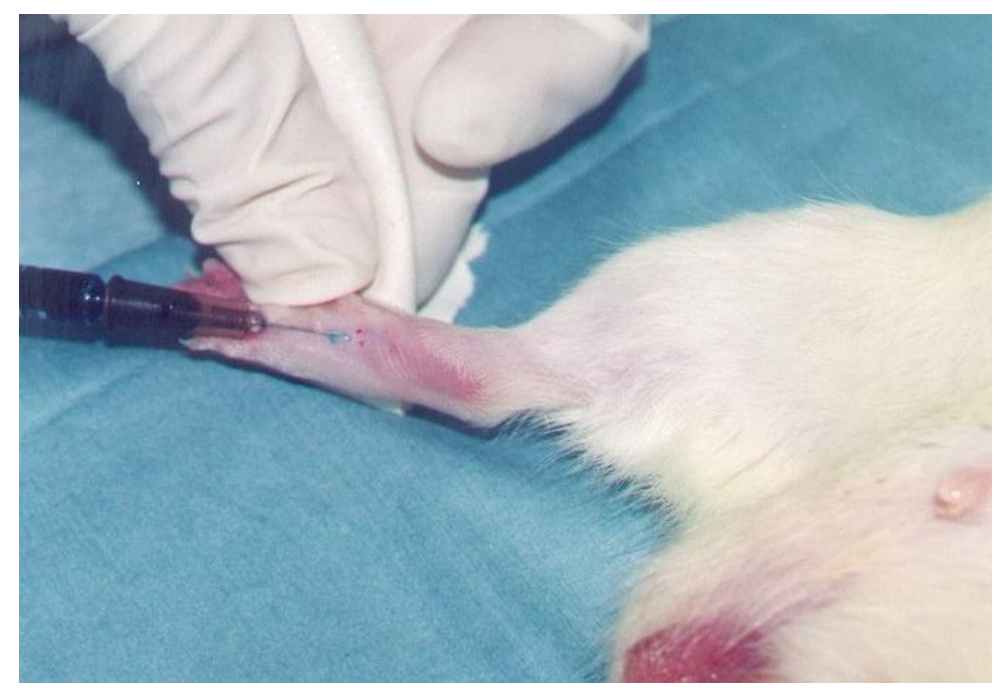

FIGURE 3 - Intrademal injection of blue dye into right posterior footpad. 


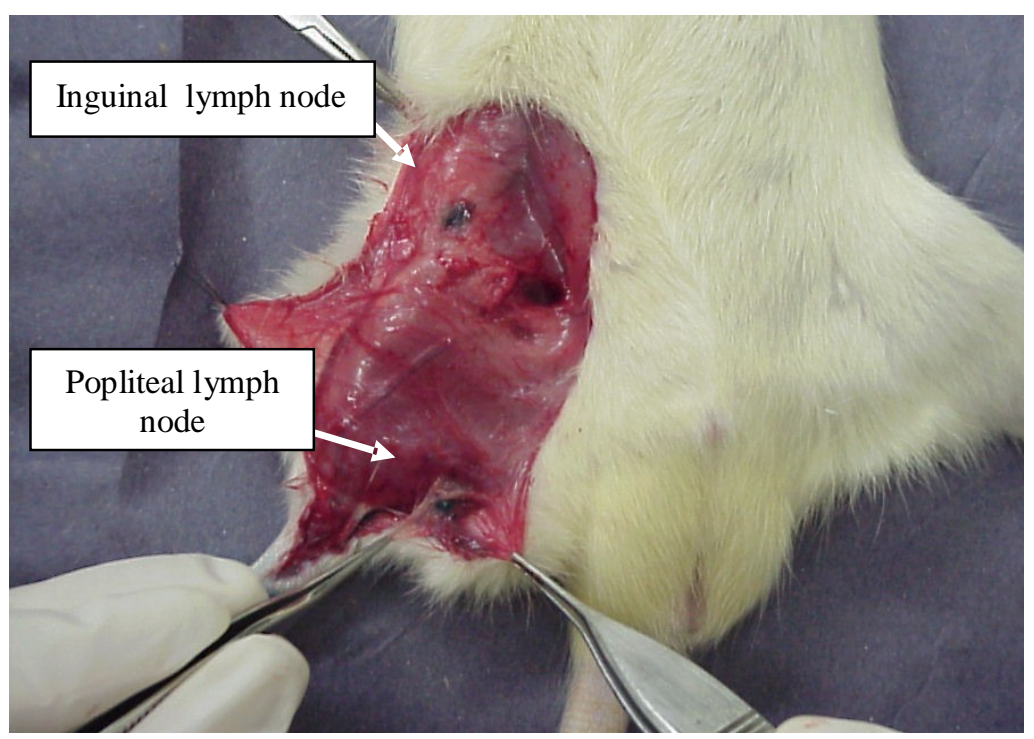

FIGURE 4 - Popliteal and inguinal lymph nodes dyed by patent blue.

\section{Perspectives}

Sentinel node biopsy plays an important role in the development of the oncologic surgery in the attempt of conducting less aggressive procedures with the same cure rates for the patients.

The experimental model in the adult rat evidences lymph nodes in the pre-operative lymphoscintigraphy, which dye blue with the proper injection of patent blue dye, retains the radiopharmaceutical to be detected by intra- operative gamma probe and may be dissected without magnification identifying sentinel lymph node.

The described experimental model demonstrated that sentinel lymph node biopsy in adult rats is feasible. Besides being useful for researches it can be used for training and diffusing this practice.

\section{References}

1. Balch CM, Buzaid AC, Soong SJ, Atinks MB, Cascinelli M, Coit DG, et al. Final Version of the American Joint Committee on Cancer Staging System for Cutaneous Melanoma. Joumal of Clinical Oncology 2001;19(16):3635-48.

2. Oliveira-Filho RS, Ferreira LM, Eto CM, Paiva GR, Wagner J. Biópsia de linfonodo sentinela no melanoma cutâneo. In: Melanoma Cutâneo Localizado e Linfonodo Sentinela. São Paulo: LEMAR;2003. p.113-24.

3. Morton DI, Thompson Jf, Esser R. Validation of the accuracy of intraoperative lymphatic mapping and sentinel Lymphadenectomy for eary-stage melanoma. Arch Surg 1992;230:453-65.

4. Pijipers R, Borgstein PJ, Meijer S, Hoeskstra S, Hattum LH, Teule GJJ. Sentinel biopsy in melanoma patients: Dynamic Lymphoscintigraphy followed by intraoperative Gamma Probe and Vital Dye Guidance. World J Surg 1997;21:788-93.

5. Oliveira Filho RS, Santos ID, Ferreira LM, de Almeida FA, Simoes e Silvia Enokihara MM, Barbieri A, Tovo Filho R. Is intra-operative gamma probe detection really necessary for inguinal sentinel lymph node biopsy? São Paulo Med J 2000 Nov 9;118(6):165-8. 
6. Neubauer S, Mena I, Iglesis R, Schwartz R, Acevedo JC, Leon A, Gomez L. Sentinel lymph node mapping in melanoma with technetium-99m dextran. Cancer Biother Radiopharm 2001 Jun;16(3):2657.

7. Oliveira-Filho RS, Ferreira LM, Barbieri A, et al. Linfadenectomia seletiva com biópsia de linfonodo sentinela no melanoma cutâneo. Experiência brasileira - Projeto FAPESP 97/02516-0. An bras Dermatol 2000;75 (5):573-80.

8. Tavares MGM, Sapienza MT, Galeb NA, Belfort FA, Costa RR, Osório CABT, et al. The use of Te ${ }^{99}$ Phytate for sentinel node mapping in melanoma, brest cancer and vulvar cancer: a study of 100 cases. Eur J Nucl Med 2001;28(11):1597-1604.

9. Bergqvist L, Strand SE, Persson BRRR. Particle sizing and biokinetics of intersticial lymphoscintigrapbic agents. Sem Nucl Med 1983;13:9-19.

10. Glass LF, Messina JL, Cruse W, Wells K, Rapaport D, Miliotes G, Berman C, Reintgen D, Fenske NA. The use of Intraoperative Radiolymphoscintigraphy for Sentinel Node Biopsy in Patients with Malignant Melanoma. Dermatol Surg 1996; 22:715-20.

11. Kitajima M. Universal application of sentinel node technology - Advent of the new era of individualized treatment of solid tumors. Abstract of III International Congress on Sentinel Node; 2002; Yokohama, Japão.

12. Woynforth HB, Flecknell PA. Specific Surgical Operations. In: Experimental and Surgical Technique in the Rat. San Diego: Academic Press;1992. p.257-63. 
Oliveira RS, Paiva GR, Ferreira LM, Wagner J, Nogueira AS. Modelo experimental em rato para biópsia de linfonodo sentinela. Acta Cir Bras [serial online] 2003 Vol 18 Edição Especial. Disponível em URL: http://www.scielo.br/acb.

RESUMO - Embora os procedimentos de biópsia de linfonodo sentinela estejam sendo reproduzidos em diversos centros oncológicos, existem muitos aspectos a serem melhor definidos e padronizados. Este trabalho tem por objetivo verificar se o modelo experimental em rato é apropriado para o procedimento de biópsia de linfonodo sentinela. No modelo experimental em rato, os linfonodos se mostram evidenciados na linfocintilografia pré-operatória, são corados pelo azul patente, captam o radiofármaco, são mensurados pelo detector portátil de radiação gama intraoperatória, e podem ser dissecados a olho nu em ratos adultos, permitindo identificação do linfonodo sentinela. $O$ modelo demonstrou que a realização de biópsia de linfonodo sentinela em ratos é factível. Isto tem um grande significado, pois, além de permitir pesquisas relacionadas a este neste tema, ele se presta também para o ensinamento do procedimento, contribuindo para a divulgação da técnica.

DESCRITORES - Biópsia de linfonodo sentinela. Modelo experimental. Ratos.

Comespondence:

Conflict of interest: none Finantial source: none

Renato Santos Oliveira Filho

UNIFESP-EPM, Plastic Surgery Division, Surgery Division

Rua Napoleão de Barros, 715, $4^{\circ}$ andar

04024-900 São Paulo - SP

Tel: (11)557604118 FAX: (11) 55716579

sandra.dcir@epm.brrenato.dcir@epm.br

Data do recebimento: 22/ 04/2003

Data da revisão: $18 / 05 / 2003$

Data da aprovação: 28/07/2003 